\title{
THE KEY AUDIT MATTERS AS AN ELEMENT OF THE INDEPENDENT AUDITOR'S REPORT - A BOOSTER TO THE CORPORATE GOVERNANCE
}

\author{
Boris Tušek * \\ Ana Ježovita **
}

\begin{abstract}
In 2009 the International Auditing and Assurance Standards Board (IAASB) initiated a project entitles 'Auditor reporting' with an objective to appropriately enhance the communicative value and relevance of the audit report. This act of the IAASB can be considered as a starting point in the revision of the International Standards on Auditing related to the structure and content of the audit report. After perennial consultations, dialogs, numerous comments received, on January 2015, the IAASB issued six revised and one new Standard related to the auditors reporting. Revised and new Standards become effective for audits of financial statements for periods ending on or after December 15, 2016. The most significant content change relates to the new Standard ISA 701 Communicating Key Audit Matters in the Independent Auditor's Report. The intention of including new paragraph(s) in the report, related to the key audit matters (KAMs), was to enhance its communication value by providing greater transparency on performed audits, and to give insights to stakeholders to the matters that, in the auditor's professional judgement, were of the most significance. The subject of the paper is to analyse changes in the structure and content of the new audit report, with a focus to the new element - KAMs. Related to the research problem, the objective of the paper will be to investigate improvements of the new audit reports, research an average number of KAMs included in one report, and make conclusions about differences between Croatian statutory auditors in prepar-
\end{abstract}

\footnotetext{
Tenured Professor at University of Zagreb, Faculty of Economics \& Business, Department of Accounting; btusek@efzg.hr

** Assistant Professor at University of Zagreb, Faculty of Economics \& Business, Department of Accounting; ajezovita@efzg.hr
} 
ing the audit report. The research covers audit reports of Croatian listed companies (public interest entities - PIEs) for 2016 and 2017. Research methodology includes using appropriate statistical methods as descriptive statistics, non-parametric tests, principal component analysis, and clustering.

KEYWORDS: financial statement audit, the International Standards on Auditing, audit report, key audit matters, materiality, listed companies, public interest entities, the IAASB, communication gap, information gap

\section{INTRODUCTION}

The objective of the audit report is to provide reasonable assurance that financial statements represent accurate and objective financial position and business performance of a company. "The integrity and credibility of financial statements are sensitive aspects that significantly influence the investors' confidence in the capital market efficiency." (Danescu, T. \& Spatacean, O., 2018, p. 111) As a corporate governance mechanism, financial statement audits have an important role in providing reliable and credible information on the truth and fairness of the financial position and business performance of a company. The credibility of financial statement was questioned several times through history, especially related to cases as Enron, HealthSouth, Kmart, Parmalat, Tyco, WorldCom, Waste Management, Sunbeam, Adelphia Communications or Xerox, in the USA, and Parmalat in Italy, Allied Nationwide Finance in New Zealand and others. Danescu \& Spatacean (2018) that those happening seriously shaken investor confidence in financial statements. Cordos \& Fülöpa (2015) went a step further questioning the auditors' reliability. After the failure of multimillion dollar companies, and as a response to an accounting scandals, numerous measures of legislation restriction have been taken, where the most prominent was new legislation on internal financial controls and financial reporting, aimed to the publicly held corporations, that came into force in 2002 known as the Sarbanes-Oxley Act (The Sarbanes-Oxley Act, web). Regarding financial statement audits, continuous efforts are being made to maintain and strengthen accountability, integrity and credibility of statutory auditors and audit reports.

In the context of accountability and integrity of statutory auditors and auditing firms' important role have the International Ethics Standards Board for Accountants (IESBA) that provide appropriate ethics requirements which are compiled in the Code of Ethics for Professional Accountants. Fundamental principles in the Code are integrity, objectivity, professional competence and due care, confidentiality, and professional behavior (IESBA, 2016, pp. 9-10). A 
professional accountant ${ }^{1}$ shall ${ }^{2}$ observe and comply with the Code. The obligation of professional accountants is to promote an audit profession, and in that context to gain trust and confidence of all interested parties.

Apart from statutory auditors' accountability and integrity, reliability and credibility of the audit report represents fundamental premise for user of financial statements. The stakeholders are aware of the fact that statutory auditors possess much more information on the audited company than disclosed in the audit report. It can be concluded that lack of available information presented by statutory auditors is one of the major deficiencies of the former audit report. The report was strictly standardized with narrowly defined structure. The methods and procedures of the audit process and obtained data on the company is summarized within one page, with no or very little information specific to the audited company. The only paragraph that could be specific to a company is defined by the ISA 706 Emphasis of Matter Paragraphs and Other Matter Paragraphs in the Independent auditor's report that was in the domain of auditor's professional judgement, and often not used. The informative power and usefulness of such report was questioned. "Nowadays, the users of audit reports feel that the statutory auditors have more knowledge about their companies than themselves, which in their opinion is frustrating and unsettling. Statutory auditors are being criticised for using a much too standardised language, for not explaining how they have reached the opinion they provide within the audit report, and for not communicating sufficiently with the people whose interest they should protect - shareholders and potential investors." (Cordos G. \& Fülöpa M., 2015, p. 149)

The most significant change in the new audit report that could result in narrowing communication gap includes adding new paragraph(s) related to the key audit matters (KAMs). As defined by the new ISA 701 Communicating Key Audit Matters in the Independent auditor's report KAMs are "those matter that, in the auditor's professional judgment, were of most significance in the audit of the financial statements of the current period" (IAASB, 2016, p. 776). In accordance with the Standard, statutory auditors select KAMs from matters communicated with TCWG, which result with matters that required significant auditor attention in performing the audit (IAASB, 2016, p. 776). In that context, KAMs are those matters of most significance in the audit of the current period. The new Standard provides statutory auditors with the possibility to provide company-specific information to stakeholders. The future will show

\footnotetext{
Professional accountant is official term for external auditor in the Code and USA practice, and a statutory auditor is a term used in European Union legislation.

2 Using the word 'shall' indicates a requirement to comply with the specific provision, unless an exception is permitted by the Code (IESBA, 2016, p. 9).
} 
the long-term effects of recent changes, and enhanced value of the audit report, as well as impact on decision making of interested parties. The question is, will those changes bring differences and company-specific information to stakeholders or KAMs will after an adoption period become standardized and insufficiently informative.

\section{THE RECENT EVOLUTION OF AUDITOR REPORTING}

In 2006 the International Auditing and Assurance Standards Board (independent standard-setting board of the International Federation of Accountants - IFAC) and the Auditing Standards Board (the senior technical committee designated by the American Institute of Certified Public Accountants - AICPA to issue auditing, attestation, and quality control statements) "commenced a joint initiative to commission academic research to identify, and provide information and insights on user perceptions regarding the financial statement audit and the independent auditor's report among different classes of financial statement users" (IAASB, web; project: Auditor Reporting). As it was emphasized in The Business Times (2014) the initiation of major reporting standards changes was to deliver more relevant and useful information about the entity, the financial statements and the audit. Several empirical researches that were conducted during the 2009 helped the IAASB to identify key messages regarding users' perception about the audit report. After several meetings that was held from 2010 to middle 2011, in May 2011 the IAASB issued a Consultation Paper, Enhancing the Value of Auditor Reporting: Exploring Options for Change. The objective of the paper was to determine if there are common views of key users about the usefulness and relevance of auditor reporting and to obtain an impression on the expectations and information gaps ${ }^{3}$ (IAASB web; project: Auditor Reporting).

As a result of identified issues, the Board explored options for changes which they summarized in five parts: format and structure of the standard audit report (part A), other information in documents containing audited financial statements (part B), auditor commentary on matters significant to users' understanding of the audit or the audited financial statements (part C), an enhanced corporate governance reporting model: role of TCWG regarding financial reporting and the external audit (part D), and other assurance or related services

The Board defines the expectations gap as "the difference between what users expect from the auditor and the financial statement audit, and the reality of what an audit is", and information gap as "a gap between the information they believe is needed to make informed investment and fiduciary decisions, and what is available to them through the entity's audited financial statements or other publicly available information” (IAASB, May 2011, pp. 7-8) 
on information not within the current scope of the financial statement audit (part E) (IAASB, May 2011, pp. 12-24). Next to the structure of the report, use of technical language, and the location of the auditor's opinion, a significant fragment of upcoming change represents an auditor commentary on significant matters. "Users of audited financial statements believe that the auditor possesses a great deal of information about the entity and the audited financial statements that would be of value to them in their decision making. (...) Some have suggested that expanded commentary about topics such as these in the auditor's report on the financial statements would provide greater transparency into the entity, its audited financial statements, and the audit performed." (IAASB, May 2011, p. 16). Furthermore, it has been suggested that statutory auditor should disclose additional information as identified key areas of material misstatement risks, areas of significant auditor judgment, the level of materiality applied by the statutory auditor to perform the audit, the entity's internal controls, including significant internal control deficiencies identified by the statutory auditor during the audit, areas of significant difficulty encountered during the audit and their resolution (IAASB, May 2011, p. 17). A first draft of the new audit report, presented by the Board in the Consultation paper, includes positioning the opinion in the first paragraph, followed by auditor commentary on matters significant to users'. The important questions, in the context of auditor commentary, refers to the possibility of removing paragraph 'Other matter', should paragraph 'Auditor commentary on significant matters' be mandatory for all audited entities, and which information that paragraph should cover. During the four-month period (May 15 - September 15) 82 stakeholders gave feedback on the proposed changes, and at its December 2011 meeting the IAASB approved a project proposal. "Requests for auditor communications in this area stem from the view that the auditor possesses a great deal of information" (IAASB, December 2011, pp. 10-11) In accordance with the received comments, it was clear that significant changes in the structure of the audit report will occur, and additional paragraphs regarding auditor commentary (AC) should be included.

As a result of all researches, consultation paper, commentaries, and meetings, at its June 2012 meeting, the Board approved a consultation document entitled Invitation to Comment: Improving the Auditor's Report (ITC) which clearly illustrates the suggested improvements of the future audit report (IAASB,

\footnotetext{
4 In the ISA 706 'Emphasis of Matter' is defined as a matter appropriately presented or disclosed in the financial statements that, in the auditor's judgement, is of such importance that it is fundamental to users' understanding of the financial statements, and 'Other matter' is defined as a matter other that those presented or disclosed in the financial statements that, in the auditor's judgement, is of such importance that it is fundamental to users' understanding of the audit, the auditor's responsibilities or the audit report (IAASB, 2016, p. 833).
} 
$w e b)$. At that moment, the IAASB reached general agreement on a number of improvements, where the most significant are adding 'Auditor Commentary' paragraph that will be required for public interest entities (PIEs), and auditor's conclusion on management's use of the going concern assumption (IAASB, 2012, p. 6). "Going concern is one of the fundamental pillars of corporate reporting.” (Segal, M., 2017, p. 382)

One of the major questions that arose in the context of including 'Auditor Commentary' in the audit report is related to the necessity of keeping the concepts of 'Emphasis of Matter' and 'Other Matter' paragraphs. In this phase, the IAASB was prone to replace those elements with a comprehensive concept of 'Auditor Commentary' that would provide transparent information about matters relating to the financial statements and the audit itself. "The IAASB will consider this in its standard-setting proposals, but the IAASB's preliminary view is that these concepts should be replaced by the more holistic concept of Auditor Commentary. Views from respondents in this regard would be particularly helpful." (IAASB, 2012, p. 23) In less than four months (June 21 - 08 October) 165 stakeholders submitted their comment letters. The comments they received included supporting and non-supporting opinions on adding 'Auditor Commentary' to the report. Considering the result that the majority of comments supported the concept of adding a new paragraph, the IAASB decided to continue with it (IAASB, Meeting Agenda, 6A, December 2012, p. 11). At the meeting on February 2013, among other matters, the IAASB supported to change the term Auditor Commentary (AC) to Key Audit Matter (KAM). At the June 2013 meeting, the IAASB unanimously approved the following proposed new and revised ISAs for exposure:

- ISA 700 (Revised), Forming an Opinion and Reporting on Financial Statements

- ISA 701 (New), Communicating Key Audit Matters in the Independent Auditor's Report

- ISA 260 (Revised), Communication with Those Charged with Governance

- ISA 570 (Revised), Going Concern

- ISA 705 (Revised), Modifications to the Opinion in the Independent Auditor's Report

- ISA 706 (Revised), Emphasis of Matter Paragraphs and Other Matter Paragraphs in the Independent Auditor's Report. (IAASB, web)

The exposure drafts were open for comment from July 25, 2013 through November 22, 2013. Cordos \& Fülöpa (2015) conducted an analysis of received comments regarding the KAMs concept. "A number of 138 comment letters 
was received, most of them coming from English-speaking countries, like the US, Canada and the UK. (...) For this analysis, we have only selected responses from comment letters issued by organisations, regulating bodies or individuals from within the EU. This counts for a total of 47 responses." (Cordos G. \& Fülöpa M., 2015, p. 135) The results of the analysis showed that 32 users $(66 \%)$ find beneficial inclusion of KAMs in the report and 16 users (34\%) finds proposed ISA 701 appropriate and sufficient in determining KAMs. "However, $21 \%$ of the replies consider that the framework for assessing KAM are more or less experimental, and should provide further guidance." (Cordos G. \& Fülöpa M., 2015, pp. 138-139) "Regarding the possibility for the auditor to not report any KAMs, $70 \%$ of the responses argue that this possibility should be allowed, while 9\% believe that it should not" (Cordos G. \& Fülöpa M., 2015, p. 145). Related to the most prominent question regarding the 'Emphasis of Matter' and 'Other Matter' paragraphs almost half (49\%) respondents agree with the IAASB's decision to retain them (Cordos G. \& Fülöpa M., 2015, p. 146).

After discussing the feedback on the exposure drafts at the IAASB March 2014 meeting, the agreement is reached at its June 2014 meeting, and at its September 2014 meeting the new and revised statutory auditor reporting standards was approved, which has been released in January 2015, and become effective for audits of financial statements for periods ending on or after December 15, 2016.

\section{LITERATURE REVIEW}

The most important impact of independent auditors' report improvements should be increase of transparency, disclosed relevant information and to enhance reliability of the report (Reintjes C., 2015; Cordos G. \& Fülöpa M., 2015; Botez, D., 2017; Sneller, L., Bode, R. \& Klerkx, A., 2017; Tadros, E., 2018). Considering the stakeholders' comments, standard-setters concluded that adequate way of narrowing the communication, information gap is to restructure the report, to emphasize the responsibilities of statutory auditors, and TCWG, and to provide company's specific information through KAMs. "One of the reforms is the transition from a standardised auditor's report without any company-specific information to a report that discloses company-specific information in the so-called key audit matters, significant risks of material misstatement in the company's financial statements." (Sneller, L., Bode, R. \& Klerkx, A., 2017, p. 139) Reintjes (2015) concludes that "the overall objective of the new and revised auditor reporting standards is to enhance the value and relevance of the auditor's report". (Reintjes C., 2015, p. 36) "The most prominent change in the auditor's report under the new and revised auditor reporting 
standards is the communication of key audit matters (KAM), which provides more entity-specific and audits-specific information to the users of the audited financial statements about the audit that has been performed." (Peyper, T., 2017, p. 53) "Key Audit Matters (KAMs), in the audit report in order to include more information regarding the audit mission, with the aim of improving audit communication. This proposal comes after users perception of audit reporting quality has decreased over time.” (Cordos G. \& Fülöpa M., 2015, p. 128) "The purpose of communicating key audit aspects is to increase the auditor's report communication value through the transparency of the audit. The communication of key aspects provides users with additional information on those issues considered significant by the auditor." (Botez, D., 2017, p. 74) "The key audit matters section is a positive development for auditors as it lets them highlight to the market their behind-the-scenes work." (Tadros, E., 2018, web)

The initiative was launched as a result of four research papers which were considered as a backbone for highlighting the existing disadvantages and reporting problems. Mock, Turner, Gray \& Coram (2009) gather information from focus groups and verbal protocol analysis (VPA). Different groups of stakeholders participated in the research, from accountants, bank lenders, non-professional investors, statutory auditors. A total of 53 individuals participated in the focus groups divided by category, and 16 experienced and currently-active financial analysts participated in the verbal protocol analysis. The study identified several specific issues related to user perceptions of the level of assurance provided by unqualified audit reports and the impact of such reports on user decision processes. Those issues include the level of assurance that needs to be clearly communicated to stakeholders, disclosing some aspects of materiality, assumptions made by statutory auditors regarding a going concern assumption, audit reports on internal controls, and the statutory auditor's assessment of fraud risk in regard to the level of assurance (Mock, T. J., Turner, J. L., Gray, . L., Coram, P. J. (2009), pp. 18-19). Following research conducted by Porter, Ó hÓgartaigh \& Baskerville (2009) lead to the conclusion stakeholders do not understand auditing and statutory auditors' responsibilities. The research conclusion, obtained by survey in the United Kingdom (UK) and New Zealand (NZ), is that the content of the audit report does not have a significant influence on the messages understood by reasonably knowledgeable users of financial statements, especially regarding the nature of the audit process, the respective roles of the statutory auditor and the directors, and the risk of investing in the reporting entity (Porter, B., Ó hÓgartaigh, C., Baskerville, R., 2009, p. vi). Next relevant research is related to the communication gap in which Asare \& Wright (2009) investigated understanding of the objectives and limitations of the audit report ('macro' level) and the extent to which there is congruence in the stakeholders' interpretation of technical language used in the audit report 
('micro' level). Authors found "type II gaps in the assurance obtained from the audit for evaluating company management, investment soundness of a company, and whether the company is likely to meet its strategic goals (...) Further, there were prevalent differences in the meaning attached to many of the micro level technical terms studied. For instance, we found type III gaps in the interpretation of 'test basis'. (...) However, most micro level differences were of the type II category, suggesting the need for a more targeted education of particular user groups rather than change in standards. The one type I gap related to the percent of net income that statutory auditor should use for materiality. Users had a much higher percentage suggesting potential misunderstanding of the effect of materiality on audit effort." ${ }^{\text {"5 }}$ (Asare, S. K. \& Wright, A., 2009, p. 23). The fourth research is conducted by Gold, Gronewold \& Pott (2009) who investigated the existence of an audit expectation gap. In addition to that, authors investigated difference between experienced statutory auditors' and financial statement users' perceptions concerning the reliability of audited financial statements (Gold, A., Gronewold, U. \& Pott, C., 2009, pp. 1-2). "Results indicate the persistence of an audit expectation gap based on the revised version of ISA 700 with its new wording for the auditor's report. We further investigate the importance of the information provided in the ISA 700 audit report by comparing user perceptions based on the complete long-form versus a short-form opinion-only audit report." (Gold, A., Gronewold, U. \& Pott, C., 2009, p. 26) Overall, the authors concluded that "the comprehensive explanations of auditor vs. management responsibilities and of the task and scope of the audit in the new ISA 700 auditor's report are not effective in reducing the audit expectation gap and in part can even have a detrimental effect." (Gold, A., Gronewold, U. \& Pott, C., 2009, p. 28)

During the almost eight-year period (2010-2017) of preparation, drafting, issuing proposals, receiving and analyzing comments, two implementation years, and two application years, researchers investigated the role and possible implication report's structure and content changes. Davidson (2015) discusses the role of the audit committee, and will their role be expanded to assessing

\footnotetext{
The authors ,consider between group differences, which we classify as being consistent with one of three patterns: (i) the user groups (investors and lenders) differ from the auditor group (which we define as a "type I communication gap"); (ii) one user group and the auditor group differ from the other user group ("type II" gap); and (iii) the user groups differ from each other as well as from the auditor group ("type III gap"). Arguably, a type I gap is of the greatest concern to standard setters, since it represents a fundamental communication gap between the issuers and users of the SAR and is likely to lead to misinterpretation and potentially litigation. A type II gap potentially represents an opportunistic communication gap, driven by a particular user's context and a type III gap represents a complete absence of shared meaning." (Asare, S. K. \& Wright, A., 2009, p. 3)
} 
KAM's. "As the auditor's KAM will highlight certain financial statement disclosures, the knowledge gained from interactions with the auditor will help the audit committee to evaluate whether those disclosures are relevant and sufficient, assisting them in discharging their duties." (Davidson, T., 2015, p. 36) The proposition of KAMs provoked the most questions and doubts regarding changes. "KAM and the reporting thereof is a fundamental shift in the nature of the audit report." (Segal, M., 2017, p. 387) Reintjes (2015) concludes that "the disclosure of entity-specific and audit-specific KAM is intended to increase confidence in the audit and the financial statements, as users will have more relevant information, and communication between various stakeholder will be enhanced. The value of the audit and the auditor report and audit quality will improve. The public interest will be served." (Reintjes C., 2015, p. 38) Inclusion of KAM in the audit report should narrow the information and communication gaps. "By providing a report with more information, in an extended form, it increases its informative value, providing a better understanding of the auditor's position and its importance in the business environment." (Botez, D., 2017, p. 75)

Important question regarding implementation of the KAMs in the audit report includes decision of which and how many matters to include. Cordos \& Fülöpa (2015) point out that the statutory auditor needs to apply his professional judgement in communicating KAMs. According to the ISA 701 "the auditor shall determine, from the matters communicated with those charged with governance, those matters that required significant auditor attention in performing the audit" (IAASB, 2016, p. 776). Next to the question which matter should be classified as KAMs, important question underlined by the authors is 'how many' KAMs should be included in the report. The Standard does not determine required number of KAMs and concludes that this is the matter is of professional judgment of the statutory auditor. "While standards provide guidelines for determining whether an audit matter constitutes a KAM, there is relatively little guidance with respect to the number of KAMs that should be reported. Indeed, which and how many KAMs to report is a matter of professional judgment." (Sirois L., Bédard J. \& Bera P., 2018, p. 9) "The number of key audit matters to be included in the auditor's report may be affected by the size and complexity of the entity, the nature of its business and environment, and the facts and circumstances of the audit engagement." (IAASB, 2016, p. 788) Cordos \& Fülöpa (2015) consider that from two to seven KAMs should be included in the report. Sirois Bédard \& Bera (2018) claim that the inclusion of multiple KAMs can add complexity and dilute the statutory auditor's message. Authors concluded that "as the number of matters increases, each KAM signal becomes less salient and users will have less cognitive resources available to process them, thereby reducing their signaling effect." (Sirois L., Bédard J. 
\& Bera P., 2018, p. 10) The publication prepared by Deloitte (2017) includes the analysis of the new audit report for 50 companies in Switzerland listed at the Swiss Market Index or Swiss Performance Index. Their results show that statutory auditors on average disclosed 2.8 KAMs per group audit and 0.8 KAMs per holding company, and furthermore a quarter of analyzed reports (26\%) disclosed only one KAM, maximum number of KAMs reported was 7 (Deloitte, 2017, p. 3). More than half KAMs (62\%) are regarding goodwill and intangible assets, and significant proportion take KAMs related to revenue recognition (44\%), taxation (38\%), provisions (24\%) (Deloitte, 2017, p. 4).

In accordance with the ISA 701 the audit may result with three scenarios: (1) inclusion of KAMs in the report, (2) determining KAMs that will not be communicated in the report, and (3) not finding KAMs. "If applicable, depending on the facts and circumstances of the entity and the audit, that there are no key audit matters to communicate in the auditor's report." (IAASB, 2016, p. 150) In that case, the statutory auditor shall include a statement on this in a separate section of the report. "It was initially thought that this would be rare, but there were a number of instances where the auditor did not identify a KAM; particularly for smaller listed entities and where reporting of KAM was requested by regulators." (Peyper, T., 2017, p. 54)

Peyper (2017) emphasizes problems which appeared after the first year of application. "It is sometimes also difficult (and time consuming) to engage with management and those charged with governance (TCWG) in order to reach common ground on which matters were of most significance and therefore KAM." (Peyper, T., 2017, p. 54) Additionally, statutory auditors have a problem in articulating KAMs in the report in an understandable way. Sneller, Bode \& Klerkx (2017) investigated the audit reports of Dutch companies, as a frontrunner for the implementation of the new audit report regarding KAMs. Within 75 reports authors identified 255 KAMs of which 39 were IT related. The authors questioned whether the inclusion of KAMs helps reduce the audit information gap and expectation gap which a challenging research area, and concluded that is hard to classify and categorize IT-related KAMs in a uniform way (Sneller, L., Bode, R. \& Klerkx, A., 2017, p. 148). Sirois, Bédard \& Bera (2018) investigated the effect of communicating KAMs, its attention directing role and explore how they impact users' information-acquisition process and, in the end, whether KAMs ultimately influence their decisions. Results obtained by the authors "show that, consistent with the attention directing role of KAMs, participants access KAM-related disclosures more rapidly and devote relatively more attention to them when KAMs are communicated in the auditor's report." (Sirois L., Bédard J. \& Bera P., 2018, p. 4) Finally, it can be concluded that "the communication of KAM will evolve over time - the first few reporting periods will have a steep learning curve.” (Peyper, T., 2017, p. 55) 
Although disclosing information about materiality did not pass as obligatory within the reporting Standards changes, in context of narrowing communication and information gaps, it is interesting to notice that numerous statutory auditors communicate that information in the new audit report. Deloitte (2017) found that $48 \%$ of audit reports of 50 Switzerland listed companies have disclosed information about materiality (Deloitte, 2017, p. 15). "In 20 out of 24 reports (84) materiality was determined based on the consolidated profit before tax as a benchmark and with an average percentage of $4.9 \%$ (the median was 5\%). Profit before tax is considered as one of the most relevant financial indicator for listed companies." (Deloitte, 2017, p. 16)

\section{RESEARCH RESULTS}

The IAASBs objective of the project entitled 'Auditors reporting' was to enhance the value of the audit report in context of narrowing communication and information gaps. Six-year-long project resulted with five revised and one new International Standards on Auditing. Today, two years after revised and new Standards become effective, it is possible to investigate main changes. In accordance with the IAASB's objective, the research question is: did recent changes in the audit report resulted with delivering more relevant and useful information about the company, financial statements and audit methodology to stakeholders? The objective of the paper is to investigate if statutory auditors in Croatia respect provisions of revised and new Standards. The most significant change in the report is related to newly introduced ISA 701 Communicating Key Audit Matters in the Independent Auditor's Report. In that context, objective of the paper includes research if the application of ISA 701 show improvements in communicating KAMs in 2017 compared to 2016, and if Croatian statutory auditors managed to adjust to recent changes at once when Standards become effective, or they need a longer period for adjustment. To effectuate research objectives, we developed three research hypotheses: (1) the structure and content of the new audit report (after 2016) is significantly changed compared to the former audit report (prior to 2016); (2) there exists a significant content difference between audit reports prepared by 'big' auditors and 'small' auditors; (3) there exists content and structure improvements in new audit reports of Croatian listed companies in 2017 compared to 2016. In order to test hypotheses, and obtain conclusions, we used appropriate statistics as descriptive statistics, Mann-Whitney U Test, principal component analysis and cluster analysis. 
New ISA 701 enforcers are public-interest entities (PIE) ${ }^{6}$. The research covers public interest entities (further in text: PIEs) in Croatia that are listed on the Zagreb Stock Exchange (ZSE). In 2018, 137 PIEs were listed on the ZSE. We manage to gather audit reports for 120 PIEs in 2016 and 116 in 2017. Other PIEs did not disclose the audit report in the annual financial statements, or did not publicly disclosed financial statements at all. 38 different auditing firms (we reciprocally use term audit firms and statutory auditors) performed financial statement audits for those PIEs (Table 1).

Table 1: Structure of audit reports prepared by 'big four' and other statutory auditors

\begin{tabular}{|l|r|r|r|r|}
\hline \multirow{2}{*}{ Statutory auditors } & \multicolumn{2}{|c|}{2016} & \multicolumn{2}{c|}{2017} \\
\cline { 2 - 5 } & $\mathrm{n}$ & $\%$ & $\mathrm{n}$ & $\%$ \\
\hline Deloitte & 21 & 18 & 23 & 20 \\
\hline EY & 3 & 3 & 10 & 9 \\
\hline KPMG & 12 & 10 & 11 & 9 \\
\hline PriceWaterhouseCoopers & 30 & 25 & 26 & 22 \\
\hline 'Big Four' & $\mathbf{6 6}$ & $\mathbf{5 5}$ & $\mathbf{7 0}$ & $\mathbf{6 0}$ \\
\hline BDO Croatia & 9 & 8 & 8 & 7 \\
\hline Subtotal & $\mathbf{7 5}$ & $\mathbf{6 3}$ & $\mathbf{7 8}$ & $\mathbf{6 7}$ \\
\hline Other statutory auditors & 45 & 38 & 38 & 33 \\
\hline Total & $\mathbf{1 2 0}$ & $\mathbf{1 0 0}$ & $\mathbf{1 1 6}$ & $\mathbf{1 0 0}$ \\
\hline
\end{tabular}

Source: prepared by authors' using publicly disclosed data available at the Zagreb Stock Exchange web, [www.zse.hr], accessed on 20/07/2018.

Majority of audit firms (58\%) are registered in Zagreb. Next to statutory auditors from Zagreb, 10 audit firms are from Mediterranean Croatia (Dubrovnik, Kastav, Pula, Rijeka, Split, Šibenik, Zadar), four from Central Croatia (Čakovec, Varaždin) and two from Eastern Croatia (Osijek). Croatian Register of Audit Firms counts 230 entities, all registered as a limited liability company (LLC) (Hrvatska revizorska komora, web). Conducted research includes $16.5 \%$ of all registered audit firms.

$6 \quad$ Public-interest entities are undertakings governed by the law of a Member State and whose transferable securities are admitted to trading on a regulated market, credit institutions, insurance undertakings, and other entities designated as public-interest entities by Member States (The European Parliament and the Council, 2013, Article 2). Public-interest entities in Croatia are defined by Accounting Act. 
Table 2: Number of audits, average and total revenues, assets and employee number of PIEs by statutory auditors

\begin{tabular}{|l|r|r|r|r|r|r|r|r|}
\hline & \multicolumn{2}{|c|}{$\begin{array}{l}\text { Number } \\
\text { of audits }\end{array}$} & \multicolumn{2}{|c|}{$\begin{array}{l}\text { Revenues } \\
\text { (Sales) (in } \\
\text { million HRK) }\end{array}$} & \multicolumn{2}{c|}{$\begin{array}{l}\text { Total assets (in } \\
\text { million HRK) }\end{array}$} & \multicolumn{2}{c|}{$\begin{array}{c}\text { Employee } \\
\text { number }\end{array}$} \\
\cline { 2 - 10 } & \multicolumn{1}{c|}{$\mathrm{n}$} & \multicolumn{1}{c|}{$\%$} & Mean & Sum & Mean & Sum & Mean & Sum \\
\hline Deloitte & 44 & 18.6 & 1,026 & 17,444 & 3,058 & 51,985 & 725 & 31,887 \\
\hline EY & 13 & 5.5 & 926 & 40,728 & 7,548 & 332,103 & 3,044 & 39,575 \\
\hline KPMG & 23 & 9.7 & 4,022 & 52,281 & 10,942 & 142,251 & 2,267 & 52,139 \\
\hline $\begin{array}{l}\text { PriceWaterhouse- } \\
\text { Coopers }\end{array}$ & 56 & 23.7 & 1,384 & 31,832 & 9,302 & 213,939 & 1,593 & 89,227 \\
\hline BDO Croatia & 17 & 7.2 & 1,388 & 77,751 & 4,047 & 226,646 & 1,882 & 31,989 \\
\hline $\begin{array}{l}\text { Other statutory } \\
\text { auditors }\end{array}$ & 83 & 35.2 & 252 & 20,883 & 480 & 39,859 & 417 & 34,570 \\
\hline
\end{tabular}

Source: prepared by authors' using publicly disclosed data available at the Zagreb Stock Exchange web, [www.zse.hr], accessed on 20/07/2018.

The data in Table 2 show that KPMG performed audits for PIEs with the largest average revenues, total assets and employee number, and BDO Croatia audited the largest market share of PIEs. It is evident that small audit firms preformed audits for smaller PIEs. Conducted analysis gives us information that over $40 \%$ of PIEs are registered in the city of Zagreb. The highest proportion of PIEs are registered in the Mediterranean Croatia (43\%), and their main business activity is related to tourism (Table 3 ).

Table 3: PIEs by regions

\begin{tabular}{|l|r|r|r|r|}
\hline \multirow{2}{*}{ Number PIEs per region } & \multicolumn{2}{|c|}{2016} & \multicolumn{2}{c|}{2017} \\
\cline { 2 - 5 } & $\mathrm{n}$ & $\%$ & $\mathrm{n}$ & $\%$ \\
\hline Eastern Croatia & 13 & 10.8 & 12 & 10.3 \\
\hline Mediterranean Croatia & 50 & 41.7 & 49 & 42.2 \\
\hline Central Croatia & 8 & 6.7 & 8 & 6.9 \\
\hline The City of Zagreb & 49 & 40.8 & 47 & 40.5 \\
\hline Total & $\mathbf{1 2 0}$ & $\mathbf{1 0 0 . 0}$ & $\mathbf{1 1 6}$ & $\mathbf{1 0 0 . 0}$ \\
\hline
\end{tabular}

Source: prepared by authors' using publicly disclosed data available at the Zagreb Stock Exchange web, [www.zse.hr], accessed on 20/07/2018. 


\subsection{CONTENT AND STRUCTURAL CHANGES IN THE AUDIT REPORT}

The first hypothesis that the structure and content of the new audit report (after 2016) is significantly changed compared to the former audit report (prior to 2016) will be tested by examining the new audit report structure and content for the listed Croatian PIEs. Former audit report is not investigated considering that their structure and content was strictly standardized and widely known.

First known fact of the former report is that the opinion was placed as the last paragraph in the report, and that the extent of the report was rarely more than one page. All examined new reports begin with the opinion what can be considered as a first signal of new Standards adoption. Next to that, descriptive statistics show that the average page number of the new report is 5.81 pages with a standard deviation of 1.36 pages. Minimum number of pages per report were 3 , and in observed two years 10 reports had the minimum page number. Maximum number of pages was 9 (six reports).

Table 4: Descriptive statistics for number of pages in audit reports

\begin{tabular}{|c|c|c|c|c|c|}
\hline & $\mathrm{n}$ & Minimum & Maximum & Mean & Std. Deviation \\
\hline Number of pages & 236 & 3 & 9 & 5.81 & 1.359 \\
\hline
\end{tabular}

Source: prepared by authors' using publicly disclosed data available at the Zagreb Stock Exchange web, [www.zse.hr], accessed on 20/07/2018.

One of the segments that were highly discussed by the IAASB, and information that would, in stakeholders' opinion, greatly narrow communication gap, is communicating details on auditors' methodology, and related to that, reporting about materiality.

Table 5: Structure of audit firms by disclosing information about materiality in the audit report

\begin{tabular}{|l|c|c|c|c|}
\hline \multirow{2}{*}{} & \multicolumn{2}{|c|}{2016} & \multicolumn{2}{c|}{2017} \\
\cline { 2 - 5 } & $\mathrm{n}$ & $\%$ & $\mathrm{n}$ & $\%$ \\
\hline Yes & 1 & 2.9 & 19 & 63.3 \\
\hline No & 34 & 97.1 & 11 & 36.7 \\
\hline Total & 35 & 100.0 & 30 & 100.0 \\
\hline
\end{tabular}

Source: prepared by authors' using publicly disclosed data available at the Zagreb Stock Exchange web, [www.zse.hr], accessed on 20/07/2018. 
Former audit report did not include information about materiality. Inclusion of materiality information in the new report is voluntary, although that information could significantly increase the value of the report. "It is considered to be one of the most important decisions of the audit and thus one of the most valuable information for users of the financial statements" (Deloitte, 2017, p. 15). Of 30 audit firms that conducted financial statement audits for 116 listed PIEs for the year 2017, 63\% (19) of them communicated materiality details in the audit report (Table 5).

Furthermore, information that needs to be communicated in the audit report for audits conducted after 2017 is information about duration of the continuous engagement period, including the year under review, and date of the first engagement. In accordance with the Auditing Act (127/2017) and Regulation (EU) No 537/2014 on specific requirements regarding statutory audit of public-interest entities and repealing Commission Decision 2005/909/EC, in order to address the familiarity threat and therefore reinforce the independence of statutory auditors and audit firms, a maximum duration of the audit engagement of a statutory auditor in a particular PIE in Croatia is seven years ${ }^{7}$ (Official Gazette, Auditing Act, Article 64). Out of 116 examined reports for the year 2017, in three reports information was not published, one report has disclosed information on lasting continuous engagement but not information about first engagement.

\footnotetext{
7 Regulation (EU) No 537/2014 in Article 41 regulates transitional provisions that: "1. As from 17 June 2020, a public-interest entity shall not enter into or renew an audit engagement with a given statutory auditor or audit firm if that statutory auditor or audit firm has been providing audit services to that public-interest entity for 20 and more consecutive years at the date of entry into force of this Regulation.

2. As from 17 June 2023, a public-interest entity shall not enter into or renew an audit engagement with a given statutory auditor or audit firm if that statutory auditor or audit firm has been providing audit services to that public-interest entity for 11 and more but less than 20 consecutive years at the date of entry into force of this Regulation.

3.Without prejudice to paragraphs 1 and 2, the audit engagements that were entered into before 16 June 2014 but which are still in place as at 17 June 2016 may remain applicable until the end of the maximum duration referred to in the second subparagraph of Article 17(1) or in point (b) of Article 17(2). Article 17(4) shall apply."

Croatian Auditing Act (127/2017) prescribes that auditing engagements contracted before 16 June 2014, in accordance with Regulation (EU) No 537/2014, can be applied until the end of the longer period of the audit engagement (10 years). Furthermore, the maximum continuous duration of audit engagements (7 years), appointed before Act enforcement, counts from the day of its appointment (Official Gazette, Auditing Act, Article 123).
} 
Table 6: Information on continuous engagement period including the year under review

\begin{tabular}{|l|r|r|}
\hline $\begin{array}{l}\text { Information on continuous engagement period including the year } \\
\text { under review }\end{array}$ & $\mathrm{n}$ & \multicolumn{1}{c|}{$\%$} \\
\hline Appointment of statutory auditor not published & 5 & 4.3 \\
\hline Published date of engagement for 2017 & 92 & 79.3 \\
\hline Published date of first engagement & 16 & 13.8 \\
\hline $\begin{array}{l}\text { Published information that statutory auditor is engaged from the } \\
\text { establishment of a company }\end{array}$ & 2 & 1.7 \\
\hline Published information on year of the first continuous engagement & 1 & 0.9 \\
\hline Total & 116 & 100.0 \\
\hline
\end{tabular}

Source: prepared by authors' using publicly disclosed data available at the Zagreb Stock Exchange web, [www.zse.hr], accessed on 20/07/2018.

Majority of examined reports has published information about the date of the engagement for year 2017 (79\%), or date of the first engagement (14\%). According to Auditing Act PIEs must appoint statutory auditors for the current year at least three months before the end of the calendar year (Official Gazette, Auditing Act, Article 41). Conducted analysis shows that nine PIEs appointed statutory auditors within last three months of 2017 (Table 6). Five of those PIEs are part of the Agrokor concern which financial statements had been re-audited in that year. Another four PIEs shall change their practices in future periods.

Table 7: Information on continuous engagement period including the year under review

\begin{tabular}{|l|r|r|}
\hline $\begin{array}{l}\text { Information on the continuous engagement period, including the } \\
\text { year under review }\end{array}$ & $\mathrm{n}$ & \multicolumn{1}{c|}{$\%$} \\
\hline Yes & 113 & 97.4 \\
\hline No & 3 & 2.6 \\
\hline Total & 116 & 100.0 \\
\hline
\end{tabular}

Source: prepared by authors' using publicly disclosed data available at the Zagreb Stock Exchange web, [www.zse.hr], accessed on 20/07/2018.

Only $2.6 \%$ of 116 audit reports for the year 2017 do not have included information on continuous engagement period, including the year under review (Table 7). 
Table 8: Descriptive statistics about continuous engagement period including the year under review

\begin{tabular}{|c|c|c|c|c|c|c|c|}
\hline & \multicolumn{6}{|c|}{ Continuous engagement period including the year under review } \\
\hline Year & Count & Mean & $\begin{array}{c}\text { Standard } \\
\text { Deviation }\end{array}$ & Median & Mode & Minimum & Maximum \\
\hline 2017 & 116 & 5 & 5 & 4 & $1^{\text {a }}$ & 1 & 25 \\
\hline
\end{tabular}

Source: prepared by authors' using publicly disclosed data available at the Zagreb Stock Exchange web, [www.zse.hr], accessed on 20/07/2018.

In Croatian PIEs, average duration of the continuous engagement period was 5 years with standard deviation 5 years (Table 8). For the half of PIEs, engagement lasted 4 years or less, and the other half of PIEs have a continuous engagement 4 years or longer. The most often the engagement duration has been one year, which is at the same time the minimum years of the engagement duration period, while the maximum continuous engagement period was 25 years.

\section{Graph 1: Number of audit reports by continuous engagement period including} the year under review

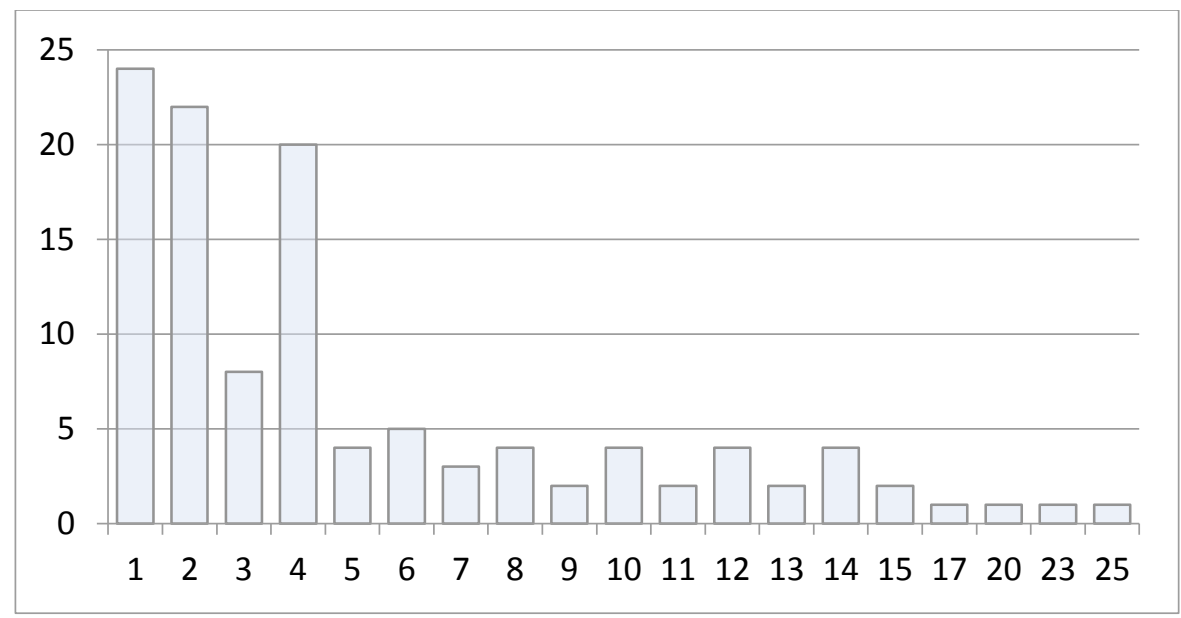

Source: prepared by authors' using publicly disclosed data available at the Zagreb Stock Exchange web, [www.zse.hr], accessed on 20/07/2018.

Graph 1 shows left-skewed distribution where can be seen that majority of continuous audit engagements lasted from 1 to 4 years. It is important to notice 
that $24.6 \%$ (28) PIEs did not change statutory auditor for more than 7 years. Moreover, three of them stated that have the same statutory auditor form the PIEs establishment. Six PIEs (5,26\%) have the same statutory auditor for more than 14 years, what is double time then allowed by the new provisions of the Act. Three analysed PIEs have the same statutory auditor for 20 years or more.

The majority would agree that the most significant change regarding the new audit report is including KAMs in the report. The new Standard (ISA 701) allows statutory auditors to be more creative and report company-specific information that would deepen the stakeholders' comprehension and cognition of PIEs.

\section{Table 9: Reporting on KAMs}

\begin{tabular}{|l|c|c|}
\hline Reporting on KAMs & Number of audit report & $\%$ \\
\hline No paragraph & 7 & 3.0 \\
\hline No KAMs & 21 & 8.9 \\
\hline Yes & 208 & 88.1 \\
\hline Total & 236 & 100.0 \\
\hline
\end{tabular}

Source: prepared by authors' using publicly disclosed data available at the Zagreb Stock Exchange web, [www.zse.hr], accessed on 20/07/2018.

Of total examined audit reports seven did not have included section about KAMs, or mention it in any way, what makes $3 \%$ of all examined reports (Table 9). Additionally, 21 reports have announcement that 'there are no key audit matters to report'. The remaining, 208 (88\%) audit reports have disclosed from 1 to 4 KAMs. The largest proportion of audit reports has communicated 1 (42\%) or $2(32 \%)$ KAMs (Table 10), and only five reports have disclosed four KAMs.

Table 10: Number of KAMs per audit report

\begin{tabular}{|l|c|c|}
\hline Number of KAMs & $\mathrm{n}$ & $\%$ \\
\hline 0 & 28 & 11.9 \\
\hline 1 & 99 & 41.9 \\
\hline 2 & 76 & 32.2 \\
\hline 3 & 28 & 11.9 \\
\hline 4 & 5 & 2.1 \\
\hline Total & 236 & 100.0 \\
\hline
\end{tabular}

Source: prepared by authors' using publicly disclosed data available at the Zagreb Stock Exchange web, [www.zse.hr], accessed on 20/07/2018. 
Considering the results obtained by the analysis, it can be concluded that the first research hypothesis, the structure and content of the new audit report (after 2016) is significantly changed compared to the former audit report (prior to 2016), can be accepted. All reports have positioned the opinion paragraph at the beginning of the report, and all reports have at least three pages. Furthermore, majority of PIEs published information on the continuous engagement duration for 2017, as well as the date of the first or current year engagement. Over $95 \%$ of the audit report applied ISA 701, and communicated KAMs.

\subsection{DIFFERENCES BETWEEN 'BIG' AND 'SMALL' AUDITORS}

Second research hypothesis includes investigating are there a significant content difference between audit reports prepared by 'big' auditors and 'small' auditors. For the research purposes, we grouped audit firms, i.e. statutory auditors, with regard to the number of conducted audits and the size of PIEs measured by total assets, revenues and employee number. In order to classify audit firms as 'big' or 'small' auditors, we used k-means cluster analysis. Clustering process includes two classifying variables, number of conducted audits per statutory auditor and the average size of the PIE. The average size of the PIE is measured by total assets, revenues and employee number. Size proxy is determined by applying principal component analysis. After obtaining new variable, we calculated average value of the proxy per statutory auditor. Variables are standardized for using in cluster analysis. The analysis resulted with two clusters: first cluster includes five cases (Deloitte, EY, KPMG, PriceWaterhouseCoopers, BDO Croatia), and second 33 cases (all other audit firms included in the research) (Table 11).

Table 11: Number of Cases in each Cluster

\begin{tabular}{|l|c|c|}
\hline \multicolumn{3}{|c|}{ Number of Cases in each Cluster } \\
\hline \multirow{2}{*}{ Cluster } & 1 & 5.000 \\
\cline { 2 - 3 } & 2 & 33.000 \\
\hline
\end{tabular}

Source: prepared by authors' using publicly disclosed data available at the Zagreb Stock Exchange web, [www.zse.hr], accessed on 20/07/2018.

Final cluster centres show the mean for each variable within each cluster, and in accordance with obtained values, it can be concluded that cases in the first cluster include audit firms that conducted more audits of bigger PIEs (Table 12). 
Table 12: Final Cluster Centres and Distances between Final Cluster Centres

\begin{tabular}{|l|c|c|}
\hline \multirow{2}{*}{ Final Cluster Centres } & \multicolumn{2}{|c|}{ Cluster } \\
\cline { 2 - 3 } & 1 & 2 \\
\hline Zscore(AuditNumber) & 2.12189 & -0.32150 \\
\hline Zscore(AvgPCA) & 1.95996 & -0.29696 \\
\hline
\end{tabular}

\begin{tabular}{|c|c|c|}
\hline \multicolumn{3}{|c|}{$\begin{array}{c}\text { Distances between Final } \\
\text { Cluster Centres }\end{array}$} \\
\hline Cluster & 1 & 2 \\
\hline 1 & & 3.326 \\
\hline 2 & 3.326 & \\
\hline
\end{tabular}

Source: prepared by authors' using publicly disclosed data available at the Zagreb Stock Exchange web, [www.zse.hr], accessed on 20/07/2018.

ANOVA table shows that both variables are important for cluster analysis ( $\mathrm{p}$-value $<0.05$ ). The higher F-value for the first variable suggests that the number of conducted audits had higher impact on determining clusters than size proxy (Table 13).

Table 13: ANOVA table for the cluster analysis

\begin{tabular}{|c|c|c|c|c|c|c|}
\hline \multicolumn{7}{|c|}{ ANOVA } \\
\hline & \multicolumn{2}{|c|}{ Cluster } & \multicolumn{2}{|c|}{ Error } & \multirow[b]{2}{*}{$\mathrm{F}$} & \multirow[b]{2}{*}{ Sig. } \\
\hline & $\begin{array}{c}\text { Mean } \\
\text { Square }\end{array}$ & df & $\begin{array}{c}\text { Mean } \\
\text { Square }\end{array}$ & $\mathrm{df}$ & & \\
\hline Zscore(AuditNumber) & 25,923 & 1 & 0,308 & 36 & 84,250 & 0,000 \\
\hline Zscore(AvgPCA) & 22,118 & 1 & 0,413 & 36 & 53,501 & 0,000 \\
\hline \multicolumn{7}{|c|}{$\begin{array}{l}\text { The F tests should be used only for descriptive purposes because the clusters have } \\
\text { been chosen to maximize the differences among cases in different clusters. The ob- } \\
\text { served significance levels are not corrected for this and thus cannot be interpreted as } \\
\text { tests of the hypothesis that the cluster means are equal. }\end{array}$} \\
\hline
\end{tabular}

Source: prepared by authors' using publicly disclosed data available at the Zagreb Stock Exchange web, [www.zse.hr], accessed on 20/07/2018.

Out of 38 audit firms, five can be classified as 'big' auditors that conducted majority financial statement audits of Croatian listed PIEs (63\% in 2016 and $67 \%$ in 2017). Onwards, other audit firms are classified as 'small' auditors. Financial statement audits of listed PIEs in Croatia in 2016 were conducted by 30, and in 2017 by 25 'small' auditors (Table 14).

Table 14: Number of audit firms classified by size

\begin{tabular}{|l|c|c|}
\hline & 2016 & 2017 \\
\hline Number of audit firms & $\mathbf{3 5}$ & $\mathbf{3 0}$ \\
\hline 'Big' auditors & 5 & 5 \\
\hline 'Small' auditors & 30 & 25 \\
\hline
\end{tabular}

Source: prepared by authors' using publicly disclosed data available at the Zagreb Stock Exchange web, [www.zse.hr], accessed on 20/07/2018. 
Table 15 shows that 'small' auditors conducted 83 (35\%) financial statement audits of PIEs in Croatia. The average revenues, total assets and employee number for PIEs audited by 'small' auditors is significantly lower than for PIEs audited by 'big' auditors.

The analysis of differences between audit reports prepared by 'big' and 'small' auditors is performed by testing characteristic of the reports for the both groups of audit firms. In order to determine differences, we choose to examine six elements of the audit report that will be the foundation for our conclusion. Those elements are: (1) number of pages, (2) opinion, (3) going concern assumption, (4) 'Other matter' paragraph, (5) materiality and (6) reported number of KAMs.

Regarding the number of pages for reports prepared by 'big' and 'small' auditors, Table 15 shows that reports of 'big' auditors on average have 6.25 pages with a standard deviation of 1.23 pages, i.e. the most often number of pages in the audit report is 6 . As opposed to that, reports prepared by 'small' auditors on average have 5.01 pages with a standard deviation of 1.22 pages, i.e. 'small' auditors most often prepared reports 5 pages long. Performed Mann-Whitney $\mathrm{U}$ test shows that there exists statistically significant difference in page numbers distributions for 'big' and 'small' auditors.

Table 15: Number of pages in audit report by audit firms' size

\begin{tabular}{|l|c|c|c|c|c|}
\hline Number of pages & Count & Mean & $\begin{array}{c}\text { Standard } \\
\text { Deviation }\end{array}$ & Median & Mode \\
\hline 'Big' auditors & 153 & 6.25 & 1.23 & 6.00 & 6.00 \\
\hline 'Small' auditors & 83 & 5.01 & 1.22 & 5.00 & 5.00 \\
\hline
\end{tabular}

Source: prepared by authors' using publicly disclosed data available at the Zagreb Stock Exchange web, [www.zse.hr], accessed on 20/07/2018.

Interesting in determining differences between 'big' and 'small' auditors is a tendency to report modified opinion. On average $28 \%$ of examined audit reports have 'Qualified Opinion', and the rest of reports have 'Unmodified Opinion' (Table 16). Over $31 \%$ of 'small' auditors published report with modified opinion compared to $26 \%$ of modified reports prepared by 'big' auditors. More detailed analysis shows us that Deloitte most often reported modified opinion (36\%), and KPMG had the lowest proportion of modified opinion (13\%). Nevertheless, Mann-Whitney U test shows that there is no statistically significant difference between opinion distribution of 'big' and 'small' auditors (empirical p-value .398 that is higher than the significance level of .05). 
Table 16: Structure of qualified opinion, significant going concern disclosure, other matter paragraph, and materiality for 'big' and 'small' auditors

\begin{tabular}{|l|c|c|c|c|c|c|c|c|}
\hline & \multicolumn{2}{|c|}{$\begin{array}{c}\text { Qualified } \\
\text { Opinion }\end{array}$} & \multicolumn{2}{c|}{$\begin{array}{c}\text { Significant } \\
\text { going concern } \\
\text { disclosure }\end{array}$} & \multicolumn{2}{c|}{$\begin{array}{c}\text { Other matter } \\
\text { paragraph }\end{array}$} & \multicolumn{2}{c|}{ Materiality } \\
\hline & $\mathrm{n}$ & $\%$ & $\mathrm{n}$ & $\%$ & $\mathrm{n}$ & $\%$ & $\mathrm{n}$ & $\%$ \\
\hline 'Big' auditors & 40 & 26.1 & 26 & 17.0 & 26 & 17.0 & 64 & 27.1 \\
\hline 'Small' auditors & 26 & 31.3 & 12 & 14.5 & 35 & 42.2 & 27 & 11.4 \\
\hline Subtotal & 66 & 28.0 & 38 & 16.1 & 61 & 25.8 & 91 & 38.6 \\
\hline
\end{tabular}

Source: prepared by authors' using publicly disclosed data available at the Zagreb Stock Exchange web, [www.zse.hr], accessed on 20/07/2018.

Another variable that could make the differences between 'big' and 'small' auditors is communicating going concern assumption. Out of 236 examined audit reports, $16 \%$ (38) had paragraph significant going concern disclosure, 19 per each observed year. The assumption was reported in $17 \%$ of reports prepared by 'big' auditors, and in $14.5 \%$ of reports prepared by 'small' auditors. According to the results of Mann-Whitney $U$ test there is no statistically significant difference in the distributions of 'big' and 'small' auditors regarding going concern assumption (p-value .614). 'Big' auditor with the highest percentage of significant going concern disclosure is PriceWaterhouseCoopers (28.6\%), followed by BDO Croatia (23.5\%), while Deloitte and KPMG had 9\% reports with the disclosure, and opposed to that EY did not have report with included going concern assumption.

A quarter (25.8\%) of examined audit reports has 'Other matter'8 paragraph. Mann-Whitney $U$ test shows that there exists statistically significant difference in reporting 'Other matter' between 'big' and 'small' auditors. The higher proportion of reports with included the paragraph issued 'small' auditors (42.2\%) compared to 'big' auditors (17.0\%). In the case of five 'big' auditors, 'Other matter' is communicated in almost half reports issued by BDO Croatia (47.1\%) and EY (46.2\%). Opposed to that, only $1.8 \%$ of reports issued by PriceWaterhouseCoopers have included 'Other matter' paragraph. The content of the paragraph is diverse and the most common reason of including paragraph in the report is to announce the change of statutory auditor $(7 ; 11.5 \%)$. Additionally, six reports with included paragraph 'Other matter', reported about the change of statutory auditor in separate section entitled 'Other questions' (6; 9.8\%), and three reports of PIEs that changed the statutory auditor for the cur-

8 For the research purposes, 'Emphasis of matter' and 'Other matter' paragraphs are complied. 
rent year, does not have that announcement. Other common announcements included in the 'Other matter' paragraph are related to the active lawsuits uncertainties regarding land ownerships (tourism PIEs), uncertainties about account receivables, liabilities, revaluation of assets and others.

Information about materiality is disclosed in $39 \%$ of all examined reports (Graph 2), and although $27 \%$ of the reports prepared by 'big' auditors compared to $11 \%$ of the reports prepared by 'small' auditors have included materiality details, existing difference is not statistically significant (p-value .162).

\section{Graph 2: Information about communicating materiality for 'big' and 'small' au- ditors}
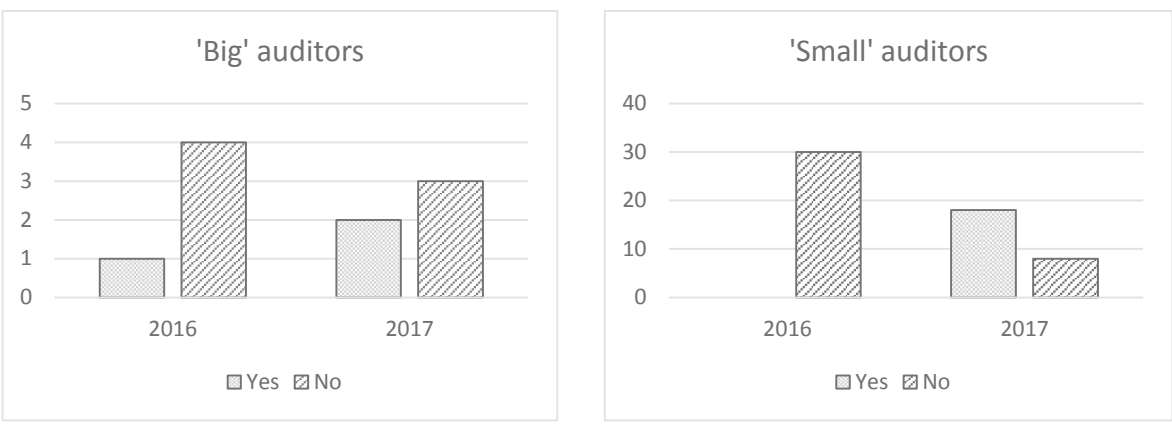

Source: prepared by authors' using publicly disclosed data available at the Zagreb Stock Exchange web, [www.zse.hr], accessed on 20/07/2018.

The most commonly used materiality base is revenue, which is used in $61.5 \%$ audits. The average materiality percentage is $1.35 \%$ of revenues with standard deviation $0.68 \%$. Minimum percentage was $0.5 \%$, maximum $3.0 \%$, and most common was $1 \%$ of revenues (Table 17).

Table 17: Materiality base and percentage

\begin{tabular}{|l|r|r|r|c|c|c|c|c|}
\hline $\begin{array}{c}\text { Materiality } \\
\text { base }\end{array}$ & \multicolumn{9}{|c|}{ Materiality percentage } \\
\hline & $\mathrm{n}$ & $\%$ & Mean & $\begin{array}{c}\text { Standard } \\
\text { Deviation }\end{array}$ & Median & Mode & Minimum & Maximum \\
\hline Assets & 12 & 13.2 & 0.97 & 0.38 & 1.00 & 1.00 & 0.50 & 2.00 \\
\hline Earnings & 22 & 24.2 & 5.57 & 2.16 & 5.00 & 5.00 & 2.50 & 10.00 \\
\hline Equity & 1 & 1.1 & 4.50 & & 4.50 & 4.50 & 4.50 & 4.50 \\
\hline Revenues & 56 & 61.5 & 1.35 & 0.68 & 1.00 & 1.00 & 0.50 & 3.00 \\
\hline & 91 & 100.0 & & & & & & \\
\hline
\end{tabular}

Source: prepared by authors' using publicly disclosed data available at the Zagreb Stock Exchange web, [www.zse.hr], accessed on 20/07/2018. 
Statutory auditors apply the materiality concept in planning and performing audit engagements, and in evaluating the effect of identified and uncorrected misstatements. "Misstatements, including omissions, are considered to be material if, individually or in the aggregate, they could reasonably be expected to influence the economic decisions of users taken on the basis of the financial statement." (IAASB, 2017, ISA 200, p. 81) In accordance with the Standards (ISA 200), the statutory auditor is responsible for the detection of misstatements that are not material. In simple words, for the amounts that exceed materiality level is considered that can influence the economic decisions of stakeholders, and on the other side, it is possible that the financial statements as whole have misstatements up to the materiality level and auditor's opinion will not be modified in respect of that. Considering that, it is understandable why materiality represents an important question to users of financial statements.

Table 18: Descriptive statistics for materiality amount by materiality base

\begin{tabular}{|l|r|r|r|r|r|r|r|}
\hline \multirow{2}{*}{$\begin{array}{c}\text { Materiality } \\
\text { base }\end{array}$} & \multicolumn{7}{|c|}{ Materiality amount } \\
\cline { 2 - 9 } & Count & \multicolumn{1}{|c|}{ Mean } & $\begin{array}{c}\text { Standard } \\
\text { Deviation }\end{array}$ & Median & Mode & Minimum & Maximum \\
\hline Assets & 12 & $3,059,583$ & $2,897,681$ & $1,700,000$ & $5,000^{\mathrm{a}}$ & 5,000 & $8,200,000$ \\
\hline Earnings & 22 & $18,269,545$ & $23,085,669$ & $8,700,000$ & $330,000^{\mathrm{a}}$ & 330,000 & $75,000,000$ \\
\hline Equity & 1 & $7,550,000$ & & $7,550,000$ & $7,550,000$ & $7,550,000$ & $7,550,000$ \\
\hline Revenues & 56 & $9,378,696$ & $11,408,905$ & $4,750,000$ & $1,300,000$ & 6,000 & $54,000,000$ \\
\hline
\end{tabular}

a. Multiple modes exist. The smallest value is shown

Source: prepared by authors' using publicly disclosed data available at the Zagreb Stock Exchange web, [www.zse.hr], accessed on 20/07/2018.

The highest materiality level is present in audit reports for PIEs in which statutory auditors used earnings as a materiality base (Table 18). The average materiality level for the financial statements of those PIEs was 18.3 million HRK with a standard deviation of 23 million HRK. The minimum materiality level was 330 thousand HRK, and it was for the financial statements of the PIE that had 121.4 million HRK of total assets, and 43 million HRK of revenues (sea transport). The highest materiality level is determined in amount of 75 million HRK, and refers to the PIE with 15.7 billion HRK of total assets, and 7.9 billion HRK of revenues (telecommunication services). As it was stated earlier, the largest number of reports has revenue as materiality base, with most common materiality level of 1.3 million HRK. 
Table 19: Descriptive statistics for number of KAMs for 'big' and 'small' auditors

\begin{tabular}{|l|c|c|c|c|c|}
\hline \multicolumn{1}{|c|}{ Number of KAMs } & Count & Mean & $\begin{array}{c}\text { Standard } \\
\text { Deviation }\end{array}$ & Median & Mode \\
\hline 'Big' auditors & 153.0 & 1.7 & 0.9 & 2.0 & 1.0 \\
\hline 'Small' auditors & 83.0 & 1.1 & 0.9 & 1.0 & 1.0 \\
\hline
\end{tabular}

Source: prepared by authors' using publicly disclosed data available at the Zagreb Stock Exchange web, [www.zse.hr], accessed on 20/07/2018.

'Big' and 'small' auditors most commonly issued reports with included only one KAM, but half of 'big' auditors issued reports with 2 or more KAMs (Table 19). On average, 'big' auditors, disclosed 1.7 KAMs with a standard deviation of 0.9 KAMs, and 'small' auditors disclosed 1.1 KAMs with a standard deviation of 0.9 KAMs. Mann-Whitney U test shows that the difference between 'big' and 'small' auditors is statistically significant. The PriceWaterhouseCoopers reported the highest number of KAMs, on average 1.9 per report.

Table 20: KAMs structure

\begin{tabular}{|l|c|c|c|c|}
\hline KAMs structure & $\mathbf{1}$ & $\mathbf{2}$ & $\mathbf{3}$ & $\mathbf{4}$ \\
\hline Revenue recognition & 42 & 4 & 3 & $/$ \\
\hline Capitalization & 5 & 3 & & $/$ \\
\hline Estimates & 14 & 8 & 2 & $/$ \\
\hline Impairments & 39 & 28 & 5 & $/$ \\
\hline Valuation & 39 & 15 & 9 & 2 \\
\hline Property, plant and equipment & 7 & 2 & $/$ & $/$ \\
\hline Collectability of receivables & $/$ & 4 & $/$ & $/$ \\
\hline Before bankruptcy settlement & 4 & 1 & $/$ & $/$ \\
\hline Contingent liabilities and litigation settlements & 7 & 8 & 1 & $/$ \\
\hline Provisions & 12 & 4 & 2 & 1 \\
\hline Construction contracts & 4 & $/$ & $/$ & $/$ \\
\hline Accumulated depreciation & 1 & 4 & 2 & $/$ \\
\hline Going concern assumption & 1 & $/$ & 2 & $/$ \\
\hline Other & 35 & 24 & 7 & 2 \\
\hline Total & 210 & 105 & 33 & 5 \\
\hline
\end{tabular}

Source: prepared by authors' using publicly disclosed data available at the Zagreb Stock Exchange web, [www.zse.hr], accessed on 20/07/2018.

As it can be seen from the Table 20, the most common first KAM is about revenue recognition (20\%), impairments (18.6\%), and valuation (18.6\%). Significant proportion makes matters about estimates (6.7\%) and provisions (5.7\%). 
Table 21: Structure of impairments, valuation, estimates and provisions reported as KAMs

\begin{tabular}{|c|c|c|c|}
\hline Impairments & Valuation & Estimates & \begin{tabular}{|l|} 
Provisions \\
\end{tabular} \\
\hline $\begin{array}{l}\text { - assets } \\
\text { - assets held for } \\
\text { sale } \\
\text { - assets, factoring } \\
\text { gain } \\
\text { - brands and } \\
\text { goodwill } \\
\text { - goodwill } \\
\text { - granted loans to } \\
\text { subsidiaries } \\
\text { - intangible assets } \\
\text { - investments in } \\
\text { subsidiaries } \\
\text { - non-current } \\
\text { assets } \\
\text { - property, plant } \\
\text { and equipment } \\
\text { - receivables } \\
\text { - related parties } \\
\text { - ships } \\
\text { - test for equity } \\
\text { instrument } \\
\text { - tourist facilities }\end{array}$ & $\begin{array}{l}\text { - biological assets } \\
\text { - public partner } \\
\text { receivables - Arena } \\
\text { lessee } \\
\text { - liabilities } \\
\text { - long-term liabilities } \\
\text { - tourist facilities } \\
\text { - intangible assets } \\
\text { - inventories } \\
\text { - land and buildings } \\
\text { - non-financial financial } \\
\text { instruments } \\
\text { - granted loans to } \\
\text { subsidiaries and } \\
\text { unrelated third parties } \\
\text { - related parties } \\
\text { receivables } \\
\text { - account receivables } \\
\text { - property, plant and } \\
\text { equipment } \\
\text { - liabilities from the } \\
\text { insurance contract and } \\
\text { the adequacy test of } \\
\text { liabilities } \\
\text { - ships recoverable } \\
\text { amount } \\
\text { - technical reserves } \\
\text { - related parties' } \\
\text { investment } \\
\text { - technological oil } \\
\text { - }\end{array}$ & $\begin{array}{l}\text { - technical } \\
\text { reserves } \\
\text { - real estate } \\
\text { - tourist } \\
\text { facilities } \\
\text { - unlimited } \\
\text { useful life of } \\
\text { brands and } \\
\text { licenses } \\
\text { - lawsuit and } \\
\text { claims } \\
\text { - useful life of } \\
\text { the property, } \\
\text { plant and } \\
\text { equipment } \\
\text { - hydrocarbon } \\
\text { reserves }\end{array}$ & $\begin{array}{l}\text { - loan losses } \\
\text { - litigation } \\
\text { settlements } \\
\text { and contingent } \\
\text { liabilities } \\
\text { - leaving } \\
\text { the field } \\
\text { estimation } \\
\text { - warranty } \\
\text { obligations } \\
\text { - contingent } \\
\text { liabilities }\end{array}$ \\
\hline
\end{tabular}

Source: prepared by authors' using publicly disclosed data available at the Zagreb Stock Exchange web, [www.zse.hr], accessed on 20/07/2018.

As it can be seen in the Table 21, disclosures related to valuation are the most diverse, followed by impairments disclosures. Reports include total $28 \mathrm{KAMs}$ related to the granted loan impairments $(1 / 19 ; 2 / 9 ; 3 / 0 ; 4 / 0), 15$ KAMs related to the valuation of land, buildings and tourist facilities $(1 / 11 ; 2 / 3 ; 3 / 1 ; 4 / 0)$. Provisions are most often related to warranty obligations $(1 / 6 ; 2 / 3 ; 3 / 1 ; 4 / 0)$, and 13 KAMs about estimates is related to estimates of the useful life of the property, plant and equipment $(1 / 10 ; 2 / 3 ; 3 / 0 ; 4 / 0)$. 
Table 22: Results of Mann-Whitney U Test

\begin{tabular}{|c|c|c|c|c|c|}
\hline & Variable & Null Hypothesis & Test & Sig. & Decision \\
\hline 1 & $\begin{array}{l}\text { Number of } \\
\text { pages }\end{array}$ & $\begin{array}{l}\text { The distribution of } \\
\text { Number of pages is the } \\
\text { same across categories } \\
\text { of Auditor size }\end{array}$ & $\begin{array}{l}\text { Independent- } \\
\text { Samples Mann- } \\
\text { Whitney U Test }\end{array}$ & .000 & $\begin{array}{l}\text { Reject } \\
\text { the null } \\
\text { hypothesis }\end{array}$ \\
\hline 2 & Opinion & $\begin{array}{l}\text { The distribution of } \\
\text { Opinion is the same } \\
\text { across categories of } \\
\text { Auditor size }\end{array}$ & $\begin{array}{l}\text { Independent- } \\
\text { Samples Mann- } \\
\text { Whitney U Test }\end{array}$ & .398 & $\begin{array}{l}\text { Retain } \\
\text { the null } \\
\text { hypothesis }\end{array}$ \\
\hline 3 & $\begin{array}{l}\text { Going } \\
\text { concern } \\
\text { assumption }\end{array}$ & $\begin{array}{l}\text { The distribution } \\
\text { of Going concern } \\
\text { assumption is the same } \\
\text { across categories of } \\
\text { Auditor size }\end{array}$ & $\begin{array}{l}\text { Independent- } \\
\text { Samples Mann- } \\
\text { Whitney U Test }\end{array}$ & .614 & $\begin{array}{l}\text { Retain } \\
\text { the null } \\
\text { hypothesis }\end{array}$ \\
\hline 4 & $\begin{array}{l}\text { 'Other } \\
\text { matter' } \\
\text { paragraph }\end{array}$ & $\begin{array}{l}\text { The distribution of } \\
\text { 'Other matter' paragraph } \\
\text { is the same across } \\
\text { categories of Auditor } \\
\text { size }\end{array}$ & $\begin{array}{l}\text { Independent- } \\
\text { Samples Mann- } \\
\text { Whitney U Test }\end{array}$ & .000 & $\begin{array}{l}\text { Reject } \\
\text { the null } \\
\text { hypothesis }\end{array}$ \\
\hline 5 & Materiality & $\begin{array}{l}\text { The distribution of } \\
\text { Materiality is the same } \\
\text { across categories of } \\
\text { Auditor size }\end{array}$ & $\begin{array}{l}\text { Independent- } \\
\text { Samples Mann- } \\
\text { Whitney U Test }\end{array}$ & .162 & $\begin{array}{l}\text { Retain } \\
\text { the null } \\
\text { hypothesis }\end{array}$ \\
\hline 6 & $\begin{array}{l}\text { Number of } \\
\text { KAMs }\end{array}$ & $\begin{array}{l}\text { The distribution of } \\
\text { Number of KAMs is the } \\
\text { same across categories } \\
\text { of Auditor size }\end{array}$ & $\begin{array}{l}\text { Independent- } \\
\text { Samples Mann- } \\
\text { Whitney U Test }\end{array}$ & .000 & $\begin{array}{l}\text { Reject } \\
\text { the null } \\
\text { hypothesis }\end{array}$ \\
\hline
\end{tabular}

Source: prepared by authors' using publicly disclosed data available at the Zagreb Stock Exchange web, [www.zse.hr], accessed on 20/07/2018.

As it can be seen from the results, out of six observed variables, three of them have the same distribution for 'big' and 'small' auditors, and three of them show different distributions. Considering results, it is hard to make conclusions about the differences between 'big' and 'small' auditors without assignment of the weight to every included variable by using our professional judgement. In that context, as the most important variables we would outline KAMs, then variability, and number of pages. Those variables are chosen because their content is independent of PIEs business operations. If we apply that assumption, we may confirm second research hypothesis that there is a significant difference between reports prepared by 'big' auditors and 'small' auditors. 


\subsection{IMPROVEMENTS IN THE NEW AUDIT REPORTS}

Existence of content and structure improvements in new audit reports of Croatian listed companies in 2017 compared to 2016 is tested by analysing elements of audit reports in 2016 and 2017, and testing differences by using appropriate statistical tests. We selected three variables that, in our opinion, are the best improvement measurements of the audit report: (1) number of pages, (2) reporting on materiality, and (3) number of reported KAMs.

As it was stated earlier, average number of the audit report pages, observed all together, was 5.81 with a standard deviation 1.4 pages, i.e. the minimum number was 3 pages, and maximum 9 pages.

Table 23: Descriptive statistics for number of pages in audit reports by years

\begin{tabular}{|c|c|c|c|c|c|c|}
\hline Year & Mean & $\begin{array}{c}\text { Standard } \\
\text { Deviation }\end{array}$ & Median & Mode & Minimum & Maximum \\
\hline 2016 & 5.58 & 1.51 & 5.00 & 5.00 & 3.00 & 9.00 \\
\hline 2017 & 6.06 & 1.14 & 6.00 & 6.00 & 3.00 & 9.00 \\
\hline
\end{tabular}

Source: prepared by authors' using publicly disclosed data available at the Zagreb Stock Exchange web, [www.zse.hr], accessed on 20/07/2018.

Observations analyzed per year show that minimum and maximum number of pages is the same in both years, however, in 2017 the average number of pages per report is over 6 with standard deviation 1.14 pages. Considering the results that mean, median and mode are almost the same in 2017, the data distribution in that year was normalized, compared to 2016 when it was left skewed, meaning that in 2016 were more reports with fewer pages. 


\section{Graph 3: Distributions of number of pages in audit reports by years}

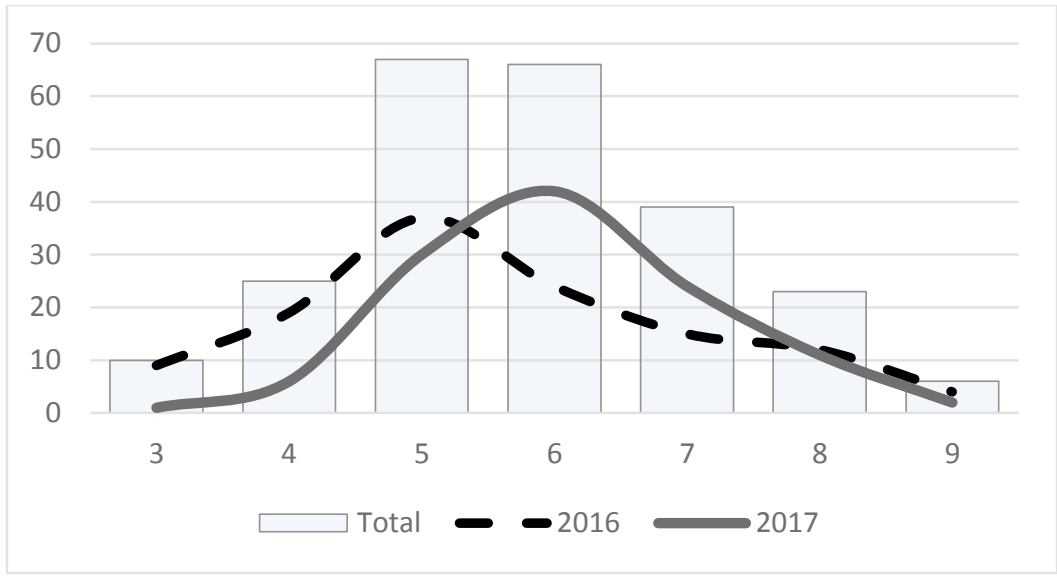

Source: prepared by authors' using publicly disclosed data available at the Zagreb Stock Exchange web, [www.zse.hr], accessed on 20/07/2018.

Graph 3 shows normalized and distribution shifted to the right in 2017 compared to 2016. The question is, are those changes statistically significant what is tested by Mann-Whitney U Test. Considering that empirical p-value is .002, and its lower than significance level .05 the null hypothesis that the distributions are the same should be rejected.

As it was shown earlier, there exists increased trend in communicating the materiality in 2017 compared to 2016. In 2016 only one statutory auditor reported detailed information about materiality, and in 201719 statutory auditors had materiality announcement, what means that 18 statutory auditors changed their approach of preparing the audit report (Table 24). Out of 18 statutory auditors that started reporting materiality details in 2017, one of them conducted two audits in that year, of which one report consist statement on materiality, and other does not. In 2016 only one of five statutory auditors classified as 'big' announces details on applied materiality and in 2017 one more statutory auditor joined him in communicating that information. It can be concluded that the increase of statutory auditors that communicates information about materiality is the result of changes in reporting of 'small' auditors. Those results may lead us to the conclusion that 'small' auditors need more adoption time compared to 'big' auditors that possesses more financial and human resources. 
Table 24: Reporting information about materiality

\begin{tabular}{|c|c|c|c|c|c|}
\hline \multirow{2}{*}{ Materiality } & \multicolumn{2}{|c|}{ No } & \multicolumn{2}{c|}{ Yes } & \multirow{2}{*}{ Total } \\
\cline { 2 - 5 } & $\mathrm{n}$ & $\%$ & $\mathrm{n}$ & $\%$ & \\
\hline 2016 & 90 & 75.0 & 30 & 25.0 & 120 \\
\hline 2017 & 55 & 47.4 & 61 & 52.6 & 116 \\
\hline Total & 145 & 61.4 & 91 & 38.6 & $\mathbf{2 3 6}$ \\
\hline
\end{tabular}

Source: prepared by authors' using publicly disclosed data available at the Zagreb Stock Exchange web, [www.zse.hr], accessed on 20/07/2018.

Out of total reports included in the analysis $38.6 \%$ have announced information on materiality, and $61.4 \%$ does not have disclosed that information. As it was emphasized earlier, disclosure of information about materiality is voluntary and represents a direct increase of the informative value of the audit report, and can be an excellent mechanism for communication and information gap reduction. Changes in 2017 compared to 2016 shows us positive trend. Proportion of reports that have included details about applied materiality increased from $25 \%$ to $52.6 \%$. We tested the statistical significance of increase, i.e. improvement of information and communication value, by using appropriate non-parametric Mann-Whitney U Test. Considering that the empirical p-value is .000 , and its lower that significance level of .05 it can be concluded that distributions for 2016 and 2017 are different.

The majority of audit reports has disclosed one (41.9\%) or two (32.2\%) KAMs. In $201618 \%$ of audit reports did not disclose KAMs. For the year 2017, that proportion decreased to 5\% (Table 25). It is undoubtedly that almost all analysed reports in 2017 have disclosed at least one KAM, but the question is, if that increase in 2017 compared to 2016 is statistically significant. The results of non-parametric Mann-Whitney U Test shows that distributions for years 2016 and 2017 are not the same, so it can be concluded that audit reports for the year 2017 have disclosed more information on PIEs, and by that it can be considered that the value of the report is improved.

Table 25: Reporting information about KAMs

\begin{tabular}{|l|c|c|c|c|}
\hline \multirow{2}{*}{} & \multicolumn{2}{|c|}{2016} & \multicolumn{2}{c|}{2017} \\
\cline { 2 - 5 } & $\mathrm{n}$ & $\%$ & $\mathrm{n}$ & $\%$ \\
\hline No & 22 & 18.3 & 6 & 5.2 \\
\hline Yes & 98 & 81.7 & 110 & 94.8 \\
\hline Total & 120 & 100.0 & 116 & 100.0 \\
\hline
\end{tabular}

Source: prepared by authors' using publicly disclosed data available at the Zagreb Stock Exchange web, [www.zse.hr], accessed on 20/07/2018. 
Although the number of reports that disclose information regarding KAMs significantly increased in 2017 compared to 2016, that increase is dominantly related to the announcement of one matter (Table 26).

Table 26: Number of KAMs included in the audit reports

\begin{tabular}{|l|c|c|c|c|c|}
\hline Number of KAMs & $\mathbf{0}$ & $\mathbf{1}$ & $\mathbf{2}$ & $\mathbf{3}$ & $\mathbf{4}$ \\
\hline 2016 & 22 & 38 & 40 & 17 & 3 \\
\hline 2017 & 6 & 61 & 36 & 11 & 2 \\
\hline
\end{tabular}

Source: prepared by authors' using publicly disclosed data available at the Zagreb Stock Exchange web, [www.zse.hr], accessed on 20/07/2018.

Related to reporting two, three or four KAMs per report, decrease for the year 2017 compared to 2016 can be noted. Considering that, the conclusion is that PIEs, which for the year 2016 had more than one KAMs, in 2017 had disclosed only one. That can be interpreted as a decrease of the informative value of the audit report. However, Mann-Whitney U Test shows that the distribution of a number of KAMs is the same across categories of year because the empirical p-value is .867, and it is higher than the significance level .05. The conclusion is in favour of the enhanced value of the audit report.

Table 27: Results of Mann-Whitney U Test

\begin{tabular}{|l|l|l|l|l|l|}
\hline & Variables & \multicolumn{1}{|c|}{ Null Hypothesis } & \multicolumn{1}{c|}{ Test } & Sig. & \multicolumn{1}{|c|}{ Decision } \\
\hline 1 & $\begin{array}{l}\text { Number of } \\
\text { pages }\end{array}$ & $\begin{array}{l}\text { The distribution of Number } \\
\text { of pages is the same across } \\
\text { categories of Year }\end{array}$ & $\begin{array}{l}\text { Independent- } \\
\text { Samples Mann- } \\
\text { Whitney U Test }\end{array}$ & .002 & $\begin{array}{l}\text { Reject } \\
\text { the null } \\
\text { hypothesis }\end{array}$ \\
\hline 2 & Materiality & $\begin{array}{l}\text { The distribution of } \\
\text { Materiality is the same } \\
\text { across categories of Year }\end{array}$ & $\begin{array}{l}\text { Independent- } \\
\text { Samples Mann- } \\
\text { Whitney U Test }\end{array}$ & .000 & $\begin{array}{l}\text { Reject } \\
\text { the null } \\
\text { hypothesis }\end{array}$ \\
\hline 3 & $\begin{array}{l}\text { Inclusion of } \\
\text { KAMs }\end{array}$ & $\begin{array}{l}\text { The distribution of } \\
\text { KAMsCode is the same } \\
\text { across categories of Years }\end{array}$ & $\begin{array}{l}\text { Independent- } \\
\text { Samples Mann- } \\
\text { Whitney U Test }\end{array}$ & .002 & $\begin{array}{l}\text { Reject } \\
\text { the null } \\
\text { hypothesis }\end{array}$ \\
\hline KAMs & $\begin{array}{l}\text { The distribution of Number } \\
\text { of KAMs is the same across } \\
\text { categories of Year }\end{array}$ & $\begin{array}{l}\text { Independent- } \\
\text { Samples Mann- } \\
\text { Whitney U Test }\end{array}$ & $\begin{array}{l}\text { Retain } \\
\text { the null } \\
\text { hypothesis }\end{array}$ \\
\hline \multicolumn{2}{|l|}{ Asymptotic significances are displayed. The significance level is .05. } \\
\hline
\end{tabular}

Source: prepared by authors' using publicly disclosed data available at the Zagreb Stock Exchange web, [www.zse.hr], accessed on 20/07/2018. 
Considering the results obtained for all improvement measurements, statistically significant differences show that statutory auditors follow new Standards, and they are improving their practices in second compared to first implementation year. The third research hypothesis that there are significant content and structure improvements in new audit reports of Croatian listed companies in 2017 compared to 2016, can be accepted. The results are also the sign that is very hard to implement and adjust to such a significant Standards change overnight. Considering that, it can be predicted that few following reporting years will be adoption period, and additional certain changes in reports' content can be expected. That represents an interesting direction for a future research. Nevertheless, we can conclude that statutory auditors are putting effort in delivering more informative audit report, what can be noted especially regarding disclosures on materiality.

\section{CONCLUSION}

Recent changes of the International Standards on Auditing regarding statutory auditors reporting resulted with significant structure and content enhancements of the audit report. Align with these changes, the research question is: did recent changes in the audit report resulted with delivering more relevant and useful information about the company, financial statements and audit methodology to stakeholders? The objective of the paper is to investigate if statutory auditors in Croatia respect provisions of revised and new Standards. The results of conducted research show that Croatian statutory auditors adjusted their reporting process to the revised and new Standards. In that context, the information value of the reports is undoubtedly enhanced. Also, the results indicate that 'small' auditors, compared to 'big', need more adjustment time to completely adopt Standards changes, but it is encouraging that reports prepared for the year 2017 are improved compared to the reports for the year 2016. The most outstanding difference between 'big' and 'small' auditors is linked to reporting the KAMs and reports' number of pages, where 'big' auditors are prone to announce more KAMs and their reports are more extensive. As a KAM, statutory auditors most frequently reported about revenue recognition, granted loan impairments, valuation of land, buildings and tourist facilities, provisions regarding warranty obligations and estimates of the useful life of the property, plant and equipment. Creditable improvement of the audit report for the year 2017 compared to 2016 is the statutory auditors' decision to voluntary announce detail information regarding applied materiality. Generally, materiality concept is one of the most important segments of audit engagements, and considering that, as very important information for stakeholders in making economic decisions using information from audited 
financial statements. Research results show that Croatian statutory auditors most commonly use $1 \%$ of revenues as materiality base, followed by $5 \%$ of earnings. It is interesting to emphasize that audit engagements based on earnings have almost two times greater misstatements thresholds than in case of revenues as materiality base. The conducted research shows that the value of the new audit report is significantly improved, and by that, communication and information gaps narrowed. Nevertheless, future research should be aimed to conduct a survey that will include stakeholders by which it would be possible to investigate their opinion regarding the audit report improvements and enhanced value. Besides, considering that additional adjustments of the report are expected within following few years, it would be beneficial to expand this research in the future, in order to gain comprehensive results about the revised and new Standards implementation phases and adjustment duration.

\section{LITERATURE}

1. Asare, S. K.; Wright, A.: Investors', Auditors' and Lenders' Understanding of the Message Conveyed By the Standard Audit Report, the AICPA Auditing Standards Board (ASB) and International Auditing and Assurance Standards Board (IAASB), September 2009, [http://www.ifac.org/system/files/downloads/ Study_3_AICPA_IAASB_Paper.pdf], accessed on 11/08/2018.

2. Botez, D.: Updates Regarding Audit Reporting. Studies and Scientific Researches: Economics Edition, O(25) 2017, pp. 71-76, DOI 10.29358/sceco.v0i25.385

- DOI: https://doi.org/10.29358/sceco.v0i25.385

3. Cordos G.; Fülöpa M.: Understanding audit reporting changes: Introduction of key audit matters. Accounting and Management Information Systems. 14(1) 2015, pp. 128-152, [https://search.proquest.com/docview/1760332939?accountid=132154], accessed on 11/08/2018.

4. Danescu, T.; Spatacean, O.: Audit opinion impact in the investors' perception empirical evidence on Bucharest Stock Exchange, Audit Financiar, 16(149) 2018, pp. 111-121, DOI 10.20869/AUDITF/2018/149/111.

- DOI: https://doi.org/10.20869/AUDITF/2018/149/111

5. Davidson T.: Audit Committee Reporting. Accountancy SA. 2015, pp. 36-37. [https://search.proquest.com/docview/1696685449?accountid=132154], accessed on $11 / 08 / 2018$.

6. Deloitte (2017) Benchmarking the new auditor's report: Key audit matters and other additional information, [https://www2.deloitte.com/content/dam/Deloitte/ ch/Documents/audit/ch-en-audit-benchmarking-auditors-report.pdf], accessed on $29 / 08 / 2018$. 
7. Gold, A.; Gronewold, U.; Pott, C.: Financial Statement Users' Perceptions of the IAASB's ISA 700 Unqualified Auditor's Report in Germany and the Netherlands, Summary Report, the Auditing Standards Board and the International Auditing and Assurance Standards Board, August 2009, [http://www.ifac.org/system/files/ downloads/Study_4_ASB_ResearchReport.pdf], accessed on 11/08/2018.

8. Hrvatska revizorska komora, web [http://www.revizorska-komora.hr/], accessed on $30 / 08 / 2018$.

9. IAASB (2011a) Enhancing the Value of Auditor Reporting: Exploring Options for Change, Consultation Paper, [https://www.ifac.org/system/files/publications/ exposure-drafts/CP_Auditor_Reporting-Final.pdf], accessed on 23/08/2018.

10. IAASB (2011b) Meeting Agenda (5A) [http://www.iaasb.org/system/files/meetings/files/20111205-IAASB-Agenda_Item_5-A-Auditor_\%20Reporting_Draft_ Project_Proposal-final-v2-06.pdf], accessed on 23/08/2018.

11. IAASB (2012) Invitation to Comment: Improving the Auditor's Report (ITC) [https://www.ifac.org/system/files/publications/files/Auditor_Reporting_Invitation_to_Comment-final_0.pdf], accessed on 23/08/2018.

12. IAASB (2012) Meeting Agenda, 6A, December 2012 [http://www.iaasb.org/ system/files/meetings/files/20121210-IAASB-Agenda_Item_6A-AR_Auditor_ Commentary-final_0.pdf], accessed on 23/08/2018.

13. IAASB (2016) Handbook on International Quality Control, Auditing, Review, Other Assurance, and Related Services Pronouncements, 2016-2017 Edition, Volume I [http://www.ifac.org/system/files/publications/files/2016-2017-IAASBHandbook-Volume-1.pdf], accessed on 25/08/2018.

14. IAASB web; project: Auditor Reporting [http://www.iaasb.org/projects/auditor-reporting], accessed on 11/08/2018.

15. IESBA (2016) The International Code of Ethics for Professional Accountants, [https://www.ethicsboard.org/system/files/publications/files/2016-IESBA-Handbook.pdf], accessed on 25/08/2018

16. Mock, T. J.; Turner, J. L.; Gray, . L.; Coram, P. J.: The Unqualified Auditor's Report: A Study of User Perceptions, Effects on User Decisions and Decision Processes, and Directions for Future Research, the Auditing Standards Board and the International Auditing and Assurance Standards Board, May 2009, [http:// www.ifac.org/system/files/downloads/Study__1_ASB_Summary_Report.pdf], accessed on 11/08/2018.

17. Official Gazette of Croatia, Accounting Act, 78/2015, 134/2015, 120/2016, [https://narodne-novine.nn.hr/clanci/sluzbeni/2015_07_78_1493.html], accessed on $27 / 08 / 2018$.

18. Official Gazette of Croatia, Auditing Act, 120/2017, [https://narodne-novine. nn.hr/clanci/sluzbeni/2017_12_127_2873.html], accessed on 27/08/2018. 
19. Peyper, T.; The New Auditor's Report, Accountancy SA, 2017, pp. 53-55. [https:// search.proquest.com/docview/1927954834?accountid=132154], accessed on 11/08/2018.

20. Porter, B.; Ó hÓgartaigh, C.; Baskerville, R.: Report on Research Conducted in the United Kingdom and New Zealand in 2008 Investigating the Audit Expectation-Performance Gap and Users' Understanding Of, and Desired Improvements To, the Audit Report, the International Auditing and Assurance Standards Board (IAASB) and the American Institute of Certified Public Accountants (AICPA), September 2009, [http://www.ifac.org/system/files/downloads/Porter_et_al_Final_Report_Combined.pdf], accessed on 11/08/2018.

21. Reintjes C.: Focus on Key Audit Matters, Accountancy SA. 2015, pp. 35-38. [https://search.proquest.com/docview/1671015872?accountid=132154], accessed on $11 / 08 / 2018$.

22. Segal, M.: ISA 701: Key Audit Matters - An exploration of the rationale and possible unintended consequences in a South African, Journal of Economic and Financial Sciences, 10(2) 2017, pp. 376-391.

- DOI: https://doi.org/10.4102/jef.v10i2.22

23. Sirois L.; Bédard J.; Bera P.: The Informational Value of Key Audit Matters in the Auditor's Report: Evidence from an Eye-tracking Study, Accounting Horizons [serial online]. January 1, 2018; (Preprints) Available from: Supplemental Index, Ipswich, MA. accessed on 10/07/2018.

24. Sneller, L.; Bode, R.; Klerkx, A.: Do IT matters matter? IT-related key audit matters in Dutch annual reports, International Journal of Disclosure and Governance, 14(2) 2017, pp. 139-151.

- DOI: https://doi.org/10.1057/s41310-016-0017-0

25. Tadros E.: Key audit matters reveal hidden taxes, The Australian Financial Review, March 2018, p. 34. [https://search.proquest.com/docview/2010806353?accountid=132154], accessed on 10/07/2018.

26. The European Parliament and the Council: Directive 2013/34/EU on the annual financial statements, consolidated financial statements and related reports of certain types of undertakings, amending Directive 2006/43/EC of the European Parliament and of the Council and repealing Council Directives 78/660/EEC and 83/349/EEC, [https://eur-lex.europa.eu/legal-content/EN/TXT/?uri=CELEX:32013L0034], accessed on 27/08/2018.

27. The International Ethics Standards Board for Accountants ${ }^{\circledR}$ (IESBA $®$ ), web [https://www.ethicsboard.org/], accessed on 25/08/2018.

28. The Sarbanes-Oxley Act [http://www.soxlaw.com/], accessed on 17/08/2018. 